\title{
新型コロナウイルス感染症の世界的流行に係る 国際協力の緊急的必要性について（仮訳）
}

新型コロナウイルス感染症が世界中に広がり、感 染者および死者の数が増え続ける中、この急速に 進行する脅威から免れている国や地域はほとんどな い。現在、新型コロナウイルス感染症の広がりを抑え、 新たな感染を特定し、患者を治療して命を救い、社 会的および経済的混乱を抑え、人間の基本的ニーズ を満たすための抜本的かつ緊急対策が、我々の社 会のあらゆるレベルで講じられている。しかし、先 行きの不透明感は拭えず、まだやるべきことは多い。 G7各国を含め、世界中の科学アカデミーが加盟す る Gサイエンス学術会議及び医学アカデミーは、こ の重大な局面において、各国内において様々な形で 取組を進めている。今こそ我々は皆、後述する次の いくつかの側面から「国際協力の緊急性」を一致し て強調することが不可欠だと考える。
1. 感染伝播、潜伏期間、致死率、各種治療介 入方法の有効性など、次第に明らかになる疫学 についての迅速かつ正確で透明性のある国際的 な意思疎通

2. 新型コロナウイルスと、ウイルスの発生源、遺 伝学、および変異、ならびに新型コロナウイル ス感染症の病態生理およびヒト免疫反応に関す る詳細な科学情報のリアルタイム共有、さらに はこれら全ての領域における知識向上のための 協調的活動

3. 新型コロナウイルス感染症医薬品の研究開発 に関する情報共有に加え、この生命に関わる研 究開発を前進させるための共同研究努力

4. 我々の相互依存に鑑み、信用できる個人用保 護具、診断検査機器、および医療対応能力の 
確保を促進するために求められる規制及び生産 過程並びに品質基準についての協調と連携

5. 世界的パンデミックの進行に伴って次々と浮上 する䋰念事項または個別の制度的・政策的課題 をエビデンスに基づいて迅速に分析するための 共同努力

6. 急速に変化する状況における一般市民および 政策立案者に向けたエビデンスに基づく一貫し た助言·指導、情報発信、およびコミュニケーショ ンの協調的な進展

これら全ての側面における国際協力および情報共 有は、まだ新型コロナウイルス感染症の本格的な影 響を受けていないものの、公衆衛生や医療基盤が 整っておらず、かつ社会情勢、経済状況、および衛 生状態が疾患の急速な蔓延に対する極度の脆弱性 と対応能力の低さを示している国や地域において特 に重要になるだろう。これは、とりわけアフリカ、ア ジア、中南米をはじめとする発展途上地域の人々に 当てはまるが、大都市圈の脆弱な地域の人々も例外 ではない。

また、新型コロナウイルス感染症がもたらす経済 的および社会的影響の様々な側面と人道上の差し 迫ったニーズを理解、予測し、備えることも急務で ある。二国間開発援助機関や国際的開発金融機関 は、国際的危機の状況下において重要な役割を果 たしてきた民間財団と同様に重要な役割を担うであ ろう。世界保健機関 (WHO) はこれらの側面の多 くに打いて中心的な存在であり、全ての国からの強 力な支持と協力を必要としている。

人類は、これまでも感染症の危険に繰り返し晒さ れてきたが、その都度、危機を克服してきた。我々 は、インフルエンザから薬䇕耐性感染症が引き起こ すパンデミック等、今後も媣刻な感染症の脅威に直 面することであろう。次なる新たな病原体の大流行 を阻止するには、環境悪化と病原媒介者との重要な 関連性に対処するための協調努力が求められる。目 下の新型コロナウイルス感染症の悲劇は、感染症の 予防および抑制に向けた取組を大幅に強化する端緒 となり、人間社会の感染症に対する備えの強化、さ らには感染症の惨禍からのレジリエンスの向上を目
指し、我々を奮い立たせるであろう。

本声明は、下記に示される15のアカデミーによ

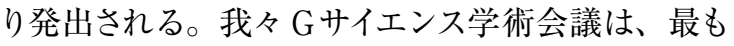
厳しい状況に置かれている国を含む世界100力国以 上が加盟するIAP (InterAcademy Partnership of Academies of Sciences and of Medicine) のメン バーでもある。IAP加盟アカデミーは、目下の新型 コロナウイルス感染症の世界的流行を克服するため に、国際的抢よび地域的協力を通じて政府、学界、 民間部門と密接に連携しながら、それぞれの国内に おいて重要な役割を果たすことが可能である。

署名：

ブラジル科学アカデミー

カナダ王立協会

フランス科学アカデミー

ドイツ科学アカデミー・レオポルデイーナ

グローバルヤングアカデミー

インド国立科学アカデミー

インドネシア科学アカデミー

イタリア・リンツェイ国立アカデミー

日本学術会議

ナイジェリア科学アカデミー

大韓民国科学技術アカデミー

ロシア科学アカデミー

英国王立協会

全米科学アカデミー

全米医学アカデミー 